\title{
CAP post 2022 scenarios and income impacts - a case analysis for selected typical farms in Slovenia
}

\author{
Jaka ŽGAJNAR ${ }^{1,2}$, Luka JUVANČIČ ${ }^{1}$, Stane KAVČIČ ${ }^{1}$, Emil ERJAVEC ${ }^{1}$
}

Received February 26, 2021; accepted March 26, 2021. Delo je prispelo 26. februarja 2021, sprejeto 26. marca 2021.

\section{CAP post 2022 scenarios and income impacts - a case analysis for selected typical farms in Slovenia}

Abstract: assessment based on representative farms is an established approach in the modern assessment of the effects of changes in agricultural policy. In line with previous CAP reforms, we can expect income redistribution impacts also with the implementation of the legislative and financial framework of the CAP for the next period. This paper discusses a scenario analysis using the farm model. The model is based on linear programming, which enables to address various technological challenges at farm level. We formed the scenarios for the analysis following the example of the scenarios contained in the impact assessment that the European Commission prepared for the CAP after 2020. The analysis involves selected farm types from selected sectors. The results suggest that the expected reduction in the envelope will generally lead to lower farm-level revenues from CAP direct payments. Consequently, economic performance will deteriorate, what is likely to be amplified in some sectors by the abolition of historical payments. The range of consequences at farm level will likely be considerable, especially for sectors and production types with a high share of CAP payments in the structure of total farm income. In certain sectors, however, there is even an improvement regarding the current situation.

Keywords: direct payments; CAP strategic plan; farm model; impact assessment
SKP po letu 2022 scenariji in vpliv na dohodek - analiza primerov izbranih tipičnih kmetijskih gospodarstev $v$ Sloveniji

Izvleček: Ocena vpliva na podlagi reprezentativnih kmetijskih gospodarstev je uveljavljen pristop v sodobnih ocenah učinkov sprememb kmetijske politike. Glede na prejšnje reforme SKP, lahko pričakujemo vplive prerazporeditve dohodka tudi $\mathrm{z}$ izvajanjem zakonodajnega in finančnega okvira SKP za naslednje obdobje. $\mathrm{V}$ prispevku obravnavamo analizo vpliva $\mathrm{z}$ uporabo modela kmetijskih gospodarstev. Model temelji na konceptu linearnega programiranja, ki omogoča reševanje različnih tehnoloških izzivov na ravni kmetijskih gospodarstev. Scenarije za analizo smo oblikovali po zgledu scenarijev iz ocene učinka, ki jo je Evropska komisija pripravila za SKP po letu 2020. Analiza vključuje izbrana kmetijska gospodarstva različnih proizvodnih usmeritev. Rezultati kažejo, da bo pričakovano zmanjšanje sredstev na ravni kmetij na splošno povzročilo manjše prihodke iz naslova neposrednih plačil SKP. Posledično se bo ekonomska slika poslabšala, kar se bo v nekaterih sektorjih dodatno odrazilo zaradi ukinitve zgodovinskih plačil. Verjeten razpon posledic na ravni kmetijskih gospodarstev bo sicer precejšen, zlasti pri sektorjih in proizvodnjah z velikim deležem plačil SKP v strukturi celotnega dohodka kmetij. Pri določenih sektorjih pa se nakazuje celo izboljšanje trenutne situacije.

Ključne besede: neposredna plačila; SKP strateški načrt; model kmetijskih gospodarstev; analiza vpliva

1 University of Ljubljana, Biotechnical Faculty, Department for Animal Science, Groblje 3, SI-1230 Domžale, Slovenia

2 Corresponding author, e-mail: jaka.zgajnar@bf.uni-lj.si 


\section{INTRODUCTION}

A new round of changes to the Common Agricultural Policy (CAP) began in 2017 and will culminate in the changing of the fundamental regulations of the CAP. The direction and tone of these changes were outlined by the Communication from the European Commission, and set out more concretely in its legislative proposals (European Commission, 2018a). The most obvious changes are the shift toward a more result-oriented agricultural policy and a clear commitment to policy that is based on facts and an established intervention logic (Lovec et al., 2020), which is to be specified by the Member States' Strategic Plans. These plans will for the first time encompass all of the CAP's measures; each Member State will choose its agricultural policy priorities and, in accordance with common principles, also determine the type, allocated funds and scope of individual measures. It is evident that there is a targeted expansion of policy toward societal goals related to food production, natural resources and the countryside. The substantive areas and the framework of CAP measures remain largely unchanged, except for a clear intention to strengthen environmental measures (Šumrada et al., 2020).

EU Member States have different discourses on agricultural policy (Coleman, 1998; Daugbjerg \& Swinbank, 2016; Alons, 2019; Erjavec \& Erjavec, 2020), which can be classified into three basic groups, each with its own emphases and accompanying policy priorities and preferred measures: a production-oriented (mercantilist) discourse, a neoliberal discourse and an environmental discourse (multifunctionality). Using the same logic, it is possible to distinguish three fundamental approaches to agricultural policy and formulate different agricultural policy scenarios.

Impact assessment of different scenarios should be part of an evidence-based approach of agricultural policy and should help decision-makers in planning policies, including the EU's Common Agricultural Policy (Lee et al., 2006). Impact assessment needs to be linked to the various indicators that are relevant to the assessment and monitoring of agricultural policy. In line with the CAP concept, indicators pertain to all three areas of sustainability by assessing economic, environmental and social aspects (European Commission, 2020).

Among the economic aspects of the CAP, the issue of farm income retains its dominant role (Hill 2018). The amended agricultural policy measures can have a significant impact on incomes in agriculture at the aggregate level and at the level of individual farms. A particularly politically sensitive issue is the redistribution of payments between farms (Sinabell et al., 2013; Severini \& Tantari, 2015), which can also significantly determine the choice of the direct payment scheme in each Member State. Analytical insight into the effects of different scenarios on the economics of farms is therefore an important issue for planning future agricultural policy measures, as well as for directing the further development of the entire industry.

In support of planning, farm models have been developing for almost two decades, gradually complementing the previously prevailing sectoral models based on partial and general equilibria (Van Tongeren et al., 2001; Langrell et al., 2013). Farm level modelling requires comprehensive data sources at farm level. This becomes a central issue for both EU policy makers and researchers. Langrell et al. (2013) mention (i) data availability and (ii) quality as the key challenges in using farm models for policy analysis at EU level. The effects of changed income conditions are then habitually monitored at the level of average farms that use accountancy (e.g. in the EU FADN system). However, the evaluation of results at the level of typical farms is increasingly used as well (Reidsma et al., 2018). These are generally either real or hypothetical farms that best represent the situation in a certain segment of an individual sector (representative farms) and allow for generalisation at the aggregate level.

The aim of this work is to examine the income issue and redistributive effects of different potential scenarios of the future CAP at the level of typical farms in Slovenia. Unlike the analytical tools developed in Slovenia so far, which primarily examined the effects of the CAP on the income position of Slovenian agriculture at the level of individual agricultural markets (Kavčič \& Erjavec, 2003; Salomon et al., 2018) or the distributive effects of the changed direct payments policy on Slovenian agriculture (Rednak et al., 2005), this paper presents analyses based at the level of typical farms taken from (Rednak et al., 2009).

To this end, we upgraded the farm model, which allows to simulate economic indicators at farm level by means of Model-calculations ${ }^{3}$ prepared by Agricultural institute of Slovenia (AIS, 2019). This approach builds on our previous work (Volk et al., 2017) and we aspired to test it and determine its applicability to scenario assessment of changes in agricultural policy.

In this paper, we thus try to evaluate gross margin changes in individual selected types of farms. Our premise was that the changed method of implementing CAP measures also affects the production decisions of farms, and thus indirectly also the economic indicators of their operations.

\footnotetext{
3 Static simulation models that enables simulating incomes and costs at the leve of individual production activities.
} 
The aim of our research was to explore:

- The possibilities of using model calculations as a basic data source for modelling with a farm model.

- The applicability of developed farm model to assess the effects of future CAP reforms.

- The income effects of the basic scenarios of future agricultural policy that emphasize the environmental, production or social aspects of agricultural policy.

- The redistributive effects of scenario changes for individual farm types.

In the continuation, we briefly present the approach used, starting with a short description of developed farm model and followed by presentation of the farms considered within the framework of this survey. We then briefly present the key assumptions of the reform scenarios, followed by presentation of the results and key findings.

\section{MATERIAL AND METHODS}

\subsection{FARM MODEL}

For the purpose of the research, we used the farm model that is based on Model calculations (MC), developed at the Agricultural Institute of Slovenia (AIS 2019). The farm model is based on a modular approach; independent modules have been developed for individual phases of analysis, which enable a comprehensive analysis of the farm production plan. The farm model is organised in the form of spreadsheets in MS Excel, with the majority of operations being automated using Visual Basic (VBA) macros, which enables relatively simple microeconomic analyses and adjustment of MC to the production activities of analysed farms.

The basic purpose of Model calculations is to monitor the costs and income situation in the production of individual agricultural product (farm activity). MCs are independent simulation models that, based on the defined (selected) initial technological parameters, enable the estimation of input consumption and thus of production costs for an individual agricultural product. The consumption of inputs depends on production technology, intensity (yield), the size of the plot or herd, the slope and in some places also some other technological parameters. MCs for an individual crop include all costs associated with production, which also allows for a direct comparison of total costs with total revenue and the calculation of various economic indicators.

The farm model is a complex tool that enables the adaptation of model calculations for each individual production activity at different levels to the analysed farm. It is based on mathematical programming with constrained optimisation. This enables the use of different operation research techniques in the automated preparation of production plans, which is also the starting point for impact assessment of the CAP reform at farm level.

In the version of the farm model that was used for the purpose of this research, the model is based on classical deterministic linear programming (LP). This is a single-criterion approach that assumes that, in light of changed circumstances, the decision-maker (i.e., farm manager) makes decisions mainly based on one main goal when defining a production plan, while taking into consideration all the production and technical constraints at the farm level. The matrix of production possibilities thus represents an example of finding (optimal) production plan, in which we focus on maximizing the objective function. In our case, this was expected gross margin, which was maximised while taking into consideration a set of constraints, operating under the assumption that it is, in addition to the farm's features, one of the more important goals influencing decision-making. Both the production constraints and the production activities that can enter optimal production plan, stem from the original farm model and are described in more detail in the report by Volk et al. (2017).

The key purpose of utilising farm model, however, is not to optimise the entire production plan, but mainly to reconstruct baseline production plan and balance it based on key information that we had for each farm. Among production activities these includes also nutrition balances and other flows of intermediate consumption at the farm level.

However, due to "normative" nature of LP solutions from an economic standpoint and to partially bypassed it and to get more "positive" solution (production plan) we used a partial optimization approach (Žgajnar \& Kavčič, 2016), which is also based on LP. Namely, the characteristic of LP is that the solution can change quickly during optimization due to its relatively sensitive system of equations and basically normative approach, which can be problematic for an analysis such as this one. In the analysis of CAP reform measures, we are mainly interested in short-term changes, which do not entail a complete restructuring and reorientation of farms. We thus used this approach that enables the reconstruction of the (baseline) farm production plan in order to assess the current state of the farm and calculate various economic and physical indicators, assuming that the production plan is also technologically appropriate (e.g. nutrition balance, stock balance). Mathematically, this means a complex system of additional equations, which enables finding the values of variables that are unknown in such a 
way that the farm production plan is complete and technologically consistent.

When we define all the given activities or at least the lower and upper limits, the described problems of reconstruction can be solved in a relatively simple way with partial optimization (equations 1 to 4). Partial optimization refers to the fact that we fix a certain part of the activities $\left(x_{f}\right)$ and demand that the solver also includes them into the optimal solution $\left(b_{f}\right)$.

$$
\begin{array}{ll}
\operatorname{maxEGM}=\sum_{j=1}^{n} c_{j} x_{j}+\sum_{f=1}^{n} c_{f} x_{f} & \\
\text { so that } & \\
\begin{array}{ll}
\sum_{j=1 ; f=1}^{n: r} a_{i j} x_{j}+a_{i f} x_{f} \leq b_{i} & \text { for all } i=1 \text { to } m \\
x_{f}=b_{f} & \text { for all } f=1 \text { to } r \\
x_{j} \geq 0 & \text { for all } j
\end{array}
\end{array}
$$

The basic idea is to estimate or calculate the missing data - variables $\left(x_{j}\right)$ using a linear program while maximizing the expected gross margin (maxEGM). Whereas all activities $\left(x_{f}\right)$ whose values (e.g. number of dairy cows, feeders, market crops, etc.) we know, we fix with additional restrictions $\left(b_{f}\right)$. In our example objective function coefficients $\left(c_{j}\right.$ and $\left.c_{f}\right)$ represent expected gross margin $(E G M)$ per each production activity in the model. It is calculated as the three-year average for variable costs and revenues for each variable, where probability for each year is the same $(1 / 3)$.

\subsection{TYPICAL FARMS}

We conducted the research on income effects of various agricultural policy options beyond 2022 using a simulation of changes in expected revenues and expected variable costs (EGM) on 11 selected types of farms (typical farms), which were defined for Slovenia within the research conducted by Rednak et al. (2009). Typical farms differ in size, production orientation and production intensity, and are located in different areas (flatlands, different kinds of less favoured area - LFA) (Table 1). Individual types characterise interesting production types of farms for agricultural policy, but they are not totally representative for Slovenian farm structure as such. They are more or less specialized in individual production ac-

\begin{tabular}{|c|c|}
\hline Production orientation & Description \\
\hline (1) Arable farming & Smaller specialised crop farm (38 ha), good conditions, grains and potato in crop rotation; flat area. \\
\hline (2) Viticulture & $\begin{array}{l}\text { Specialized viticultural farm ( } 5.2 \mathrm{ha}) \text {, white grapes, own processing, sale of wine at an average price. } \\
\text { Integrated production. }\end{array}$ \\
\hline (3) Fruit farming & $\begin{array}{l}\text { Apple production on a larger specialized farm (13 ha), large portion of plantation at peak } \\
\text { productivity, intensive yield. Integrated production; LFA: hilly. }\end{array}$ \\
\hline $\begin{array}{l}\text { (4) Milk production } \\
\text { (intensive) }\end{array}$ & $\begin{array}{l}\text { Specialised farm ( } 66 \mathrm{ha} \text { ), Holstein cattle (63), highly intensive production, sale of calves and heifers, } \\
\text { no fattening, significant proportion of grass in ration; flat area. }\end{array}$ \\
\hline $\begin{array}{l}\text { (5) Milk production } \\
\text { (medium intensity) }\end{array}$ & $\begin{array}{l}\text { Specialised farm ( } 17 \mathrm{ha}) \text {, Holstein cattle }(22) \text {, medium intensive production, sale of calves and } \\
\text { heifers, no fattening, significant proportion of grass in ration; flat area. }\end{array}$ \\
\hline $\begin{array}{l}\text { (6) Cattle farming } \\
\text { (combined breeding) }\end{array}$ & $\begin{array}{l}\text { Full-time farm (15.5 ha), Simmental cattle (16), intensive production, fattening offspring (10), } \\
\text { fodder predominantly from grassland; LFA: hilly. }\end{array}$ \\
\hline $\begin{array}{l}\text { (7) Cattle farming } \\
\text { (suckler cows) }\end{array}$ & $\begin{array}{l}\text { Part-time farm (42 ha), Simmental cattle (38), extensive production, fattening offspring (28), fodder } \\
\text { predominantly from grassland, additional purchase of a few calves; LFA: hilly. }\end{array}$ \\
\hline $\begin{array}{l}\text { (8) Cattle farming } \\
\text { (fattening bulls) }\end{array}$ & $\begin{array}{l}\text { Specialised (mixed) farm ( } 29 \mathrm{ha} \text { ), fattening bulls ( } 70) \text {, ration based on corn silage, hay and } \\
\text { purchased concentrated feed, purchase of } 200-250 \mathrm{~kg} \text { calves; flat area. }\end{array}$ \\
\hline $\begin{array}{l}\text { (9) Sheep farming } \\
\text { (lamb breeding) }\end{array}$ & $\begin{array}{l}\text { Extensive sheep farming on lower quality land ( } 147 \text { ha), Istrian pramenka sheep ( } 235 \text { breeding } \\
\text { sheep); LFA: karst; gene bank. }\end{array}$ \\
\hline $\begin{array}{l}\text { (10) Pig farming (breed- } \\
\text { ing sows + fattening) }\end{array}$ & $\begin{array}{l}\text { Larger specialised pig breeding and crop farm ( } 50 \mathrm{ha}) \text {, breeding of piglets ( } 45 \text { breeding sows) and } \\
\text { fattening ( } 878 \text { fattening pigs) at the same farm, ration based on home feed, with purchased protein } \\
\text { components. An important part of grain sold, flat area. }\end{array}$ \\
\hline $\begin{array}{l}\text { (11) Pig farming } \\
\text { (fattening) }\end{array}$ & $\begin{array}{l}\text { Larger pig feedlot on the farm (1660), purchase of piglets, ration based on home feed ( } 46 \mathrm{ha} \text { ), } \\
\text { surplus of grains sold, flat area. }\end{array}$ \\
\hline
\end{tabular}
tivities, but above all they are such that they can be visualised in Slovenian conditions.

In terms of price-cost ratios, the base year is 2017. However, since 2017 was extreme in weather and price conditions, we took into account the three-year average of prices for both production factors and products in or-

Table 1: Basic characteristics of typical farms (adapted from Rednak et al., 2009) 
der to avoid these ratios blurring a more realistic picture of an individual typical farm.

\subsection{KEY ASSUMPTIONS OF SCENARIO ANALYSIS}

We formed the scenarios for the analysis following the example of the scenarios contained in the impact assessment that the European Commission prepared for the requirements of the preparation of its legislative proposals for the CAP after 2020 (European Commission, 2018b). The individual scenarios define simplification, environmental orientation, and production and societal aspects in line with the possibilities offered by the European Commission's 2018 proposal for future measures and financial framework (European Commission, 2018a) and the 2018 European Commission's original proposal for the CAP budget (Matthews, 2020). The key assumptions of individual scenarios are presented in more detail in Table 2.

Scenarios were created by determining the choice of individual measures and the amount of funds for each measure, which also enabled the calculation of the value of payments per unit of area or animal. In the simulation analysis, we mainly included measures that have a direct income effect:

- Production-decoupled support of the first CAP pillar (various forms of basic payments, green component, support for areas with natural constraints, eco-scheme, redistribution payment, support for young farmers). It is important to point out that all scenarios anticipate the abolition of existing historical payments, which are part of the basic payment in the period 20142020.

- Production-coupled support for various purposes (grains, vegetable growing, beef feeders, milk in mountain areas, suckler cows, protein crops).

- LFA payments under the second pillar.

Other agricultural policy measures have not been modelled directly, but the envelope for the above-mentioned payments was reduced because of them. Thus, we have not modelled agri-environmental and climate measures, which can play an important role on an individual farm and may have substantial income impacts. The reason for this is that the implementation of environmental and climate payments for the period after 2022 has not yet been defined in Slovenia at the time of the analysis. We also did not model the effects of the introduction of risk management measures, nor any measures for young farmers, as the attribution of these measures on typical farms would be arbitrary.
All scenarios are based on the assumption of a reduced budget in real terms for direct payments (- $4 \%)$ and reduced resources for rural development policy measures (Matthews, 2020).

\section{RESULTS AND DISCUSSION}

Results of scenario analysis for selected typical farms (Table 3) are presented individually. The effects of different scenarios on typical farms' economic results are illustrated by gross margins (GM), estimated total revenues (R) and budgetary payments (BP). For the base year (2017) and the currently valid CAP scheme, we present values in EUR and percentage changes for the other scenarios.

Arable farm (1) considered in the scenario analysis could be described as being of medium size in terms of socio-economic status (full-time farm) and production orientation; the market value of production (around EUR 68000) is improved by the production of potatoes with relatively higher revenues per unit of area. The analysed scenarios significantly change the current level of CAP income payments (around EUR 14000). A broadly set eco-scheme with a weaker environmental ambition (Scenario $\mathrm{C}_{\mathrm{b}}$ ) would result in an $11 \%$ increase in the policy-related revenues, while a single payment per hectare or an eco-scheme with stricter environmental requirements would reduce policy-related revenues by a quarter. Redistributive approaches to the design of basic payments (scenarios D and E) would lead to a one-third reduction in budgetary payments on this farm. The share of budgetary support in total revenues thus fluctuates between around 10 and $20 \%$, which places the farm among those that are relatively sensitive to potential changes in the implementation of direct CAP payments (changes in GM fluctuate between an increase of $6 \%\left(\mathrm{C}_{\mathrm{b}}\right)$ and a decrease by almost a fifth).

Budgetary support on the analysed viticultural farm (2) is relatively low (EUR 2200) in the baseline scenario, especially compared to the market revenues from wine sales. All scenarios reduce budgetary support, some by as much as two-thirds, but this does not have a large impact on the farm's revenues themselves (drop in revenues of 1-2\%). Changes in the form of agricultural support practically do not affect this farm. This farm's key challenges are related to the level and fluctuation of prices and to fluctuations in yields due to weather and climate conditions.

We see a similar picture in the case of the fruitgrowing farm (3), where the base level of CAP income is around EUR 7000. The environmentally oriented scenario $\left(\mathrm{C}_{\mathrm{b}}\right)$ leads to an increase in support here as well, while 
Table 2: Presentation of scenarios for assessing the effects of agricultural policy changes beyond 2022

\begin{tabular}{|c|c|c|}
\hline $\begin{array}{l}\text { Scenario } \\
\text { label }\end{array}$ & Short title & $\begin{array}{l}\text { Explanation (choice of measures and shares for individual measures in the national } \\
\text { envelope for direct support) }\end{array}$ \\
\hline \multirow[t]{2}{*}{$\begin{array}{l}\text { A - Baseline } \\
2017\end{array}$} & $\begin{array}{l}\text { Baseline scenario under } \\
\text { the conditions of } 2017\end{array}$ & $\begin{array}{l}\text { Production-coupled support: } 13 \% \text {; of this } 5 \% \text { support for grains; } 1.4 \% \text { for vegetable } \\
\text { growing; } 3 \% \text { for beef; } 3.5 \% \text { for dairy farming in mountain areas; } 0.1 \% \text { support for } \\
\text { protein crops; }\end{array}$ \\
\hline & & $\begin{array}{l}\text { Production-decoupled support: } 53 \% \text { of envelope is basic payment with substantial } \\
\text { historical payments for farms that had substantial production-coupled payments } \\
\text { before } 2006 \text {, mainly dairy, beef and arable crops; } 30 \% \text { of envelope is green compo- } \\
\text { nent; } 2 \% \text { of envelope for young farmers; } 2 \% \text { Areas facing natural or other specific } \\
\text { constraints (ANCs); LFA under second pillar }\end{array}$ \\
\hline
\end{tabular}

B (single Simplified scheme with No Production-coupled support;

payment) equal payments

Production-decoupled support: $88 \%$ is a basic payment scheme; $2 \%$ of the envelope for young farmers; $0 \%$ eco-schemes; LFA under second pillar and reduced due to given smaller size of envelope.

$\mathrm{C}_{\mathrm{a}} \quad$ Ultra-green model No production- coupled support;

(dark green) Production-uncoupled support: $28 \%$ is basic payment; $2 \%$ of envelope for young farmers; 60 \% eco-schemes;

LFA under second pillar reduced given smaller size of envelope and raised by $2 \%$, as was baseline scenario A.

\begin{tabular}{ll}
\hline $\mathrm{C}_{\mathrm{b}}$ & Green model medium \\
(light green) & Eco-scheme
\end{tabular}

Production-coupled support in the amount of $10 \%$; Of this $4 \%$ for grains, $3 \%$ for suckler cows, $0 \%$ for beef, and $3 \%$ for dairy in mountain areas.

Production-decoupled support: $38 \%$ is basic payment scheme (35 \% in baseline); $2 \%$ of envelope for young farmers; $25 \%$ eco-schemes; Redistributive payment $15 \%$ (for all surfaces up to $20 \mathrm{ha}$ ); LFA under second pillar and reduced due to given smaller size of envelope.

\begin{tabular}{ll}
\hline $\mathrm{D}$ & Production model with \\
(production- & $100 \%$ difference given \\
oriented) & intensity
\end{tabular}

Production-coupled support in the amount of $5 \%$, of which $2 \%$ for grains, $2 \%$ for suckler cows, $0 \%$ for beef and $1 \%$ for support for dairy in mountain areas;

Production-uncoupled support: $83 \%$ is a basic payment scheme (amount of payment depends on intensity and is corrected by a coefficient): extensive grassland ( $<0.2 \mathrm{LU} /$ ha) and medium-intensity grassland (0.2-0.5 LU/ha), meadow orchard, olive grove - baseline payment; Intensive grassland ( $>0.5 \mathrm{LU} / \mathrm{ha})-2 \mathrm{x}$ baseline payment; Fields $-2 \mathrm{x}$ baseline payment; permanent crops, hop fields, greenhouses and gardens $-3 \mathrm{x}$ baseline payment); $2 \%$ of envelope for young farmers.

LFA under second pillar reduced given smaller size of envelope.

E (socially Social model with oriented) $25 \%$ difference depending on amount of land in different categories (farm size) and LFA in second pillar

Production-coupled support in the amount of $10 \%$, of which $3 \%$ for grains, $4 \%$ for suckler cows, $0 \%$ for beef and $3 \%$ for dairy in mountain areas;

Production-uncoupled support: $78 \%$ a basic payment scheme (30 \% derived from earlier funds intended for LFA), (amount of payment depends on size of arable lands and is corrected by a coefficient (factor in each category is $25 \%$ of baseline payment); 0-5 ha $-4 \mathrm{x}$ baseline payment; $5-10$ ha $-3 \mathrm{x}$ baseline payment; 10-20 ha - 2x; 20-50 ha - 1x baseline payment; Surfaces larger than 50 ha basic payment; $2 \%$ of envelope for young farmers.

LFA under second pillar and reduced due to given smaller size of envelope.

${ }^{*} \mathrm{LU}=$ Livestock units 
Table 3: Economic indicators for selected typical farms under the envisaged CAP reform scenarios

\begin{tabular}{|c|c|c|c|c|c|c|c|}
\hline & & \multicolumn{6}{|c|}{ S C E N A R I O S ( Baseline $=100)$} \\
\hline \multirow{4}{*}{$\begin{array}{l}\text { Type of farming } \\
\text { (1) Arable farm }\end{array}$} & & $\begin{array}{l}\text { A (Baseline) } \\
2017\end{array}$ & $\begin{array}{l}\text { B (single } \\
\text { payment) }\end{array}$ & $\begin{array}{c}\mathrm{C}_{\mathrm{a}} \\
\text { (dark } \\
\text { green) }\end{array}$ & $\begin{array}{c}\mathrm{C}_{\mathrm{b}} \\
\text { (light } \\
\text { green) }\end{array}$ & $\begin{array}{l}\mathrm{D} \text { (production- } \\
\text { oriented/land } \\
\text { types) }\end{array}$ & $\begin{array}{l}\text { E (socially oriented/ } \\
\text { farm size) }\end{array}$ \\
\hline & & EUR & \multicolumn{5}{|c|}{$\%$ of baseline } \\
\hline & $\mathrm{BP}$ & 14014 & 74 & 74 & 111 & 82 & 66 \\
\hline & $\mathrm{R}$ & 88571 & 96 & 96 & 102 & 86 & 86 \\
\hline \multirow{3}{*}{ (2) Viticulture } & GM & 24977 & 86 & 86 & 106 & 90 & 81 \\
\hline & $\mathrm{BP}$ & 2236 & 97 & 99 & 80 & 38 & 38 \\
\hline & $\mathrm{R}$ & 81452 & 100 & 100 & 99 & 98 & 98 \\
\hline \multirow{3}{*}{$\begin{array}{l}\text { (3) Fruit (apple) } \\
\text { growing }\end{array}$} & GM & 54115 & 100 & 100 & 99 & 97 & 97 \\
\hline & $\mathrm{BP}$ & 6681 & 84 & 85 & 115 & 35 & 35 \\
\hline & $\mathrm{R}$ & 217467 & 99 & 100 & 100 & 98 & 98 \\
\hline \multirow{3}{*}{$\begin{array}{l}\text { (4) Milk production } \\
\text { (intensive) }\end{array}$} & GM & 116214 & 99 & 99 & 101 & 96 & 96 \\
\hline & $\mathrm{BP}$ & 29916 & 51 & 51 & 45 & 60 & 55 \\
\hline & $\mathrm{R}$ & 208748 & 93 & 93 & 92 & 87 & 89 \\
\hline \multirow{3}{*}{$\begin{array}{l}\text { (5) Milk production } \\
\text { (medium intensity) }\end{array}$} & GM & 127666 & 88 & 88 & 88 & 91 & 90 \\
\hline & $\mathrm{BP}$ & 9072 & 51 & 51 & 60 & 61 & 68 \\
\hline & $\mathrm{R}$ & 69600 & 94 & 94 & 95 & 88 & 90 \\
\hline \multirow{3}{*}{$\begin{array}{l}\text { (6) Cattle breeding } \\
\text { (combined breeding) }\end{array}$} & GM & 44124 & 90 & 90 & 92 & 92 & 94 \\
\hline & $\mathrm{BP}$ & 7852 & 55 & 55 & 60 & 64 & 70 \\
\hline & $\mathrm{R}$ & 55530 & 94 & 94 & 94 & 88 & 90 \\
\hline \multirow{3}{*}{$\begin{array}{l}\text { (7) Cattle breeding } \\
\text { (suckler cows) }\end{array}$} & GM & 32112 & 89 & 89 & 91 & 92 & 93 \\
\hline & $\mathrm{BP}$ & 18003 & 80 & 82 & 62 & 91 & 77 \\
\hline & $\mathrm{R}$ & 85045 & 96 & 96 & 92 & 85 & 86 \\
\hline \multirow{3}{*}{$\begin{array}{l}\text { (8) Cattle breeding (bull } \\
\text { fattening) }\end{array}$} & GM & 33918 & 89 & 90 & 80 & 95 & 88 \\
\hline & $\mathrm{BP}$ & 15797 & 49 & 49 & 74 & 54 & 45 \\
\hline & $\mathrm{R}$ & 112100 & 92 & 92 & 96 & 87 & 87 \\
\hline \multirow{3}{*}{$\begin{array}{l}\text { (9) Sheep farming } \\
\text { (lamb breeding) }\end{array}$} & GM & 24699 & 68 & 68 & 83 & 71 & 65 \\
\hline & $\mathrm{BP}$ & 35971 & 152 & 156 & 201 & 34 & 95 \\
\hline & $\mathrm{R}$ & 58888 & 132 & 134 & 162 & 60 & 60 \\
\hline \multirow{4}{*}{$\begin{array}{l}\text { (10) Pig farming } \\
\text { (breeding sows + } \\
\text { fattening) }\end{array}$} & GM & 30289 & 147 & 151 & 205 & 23 & 94 \\
\hline & $\mathrm{BP}$ & 18767 & 70 & 70 & 110 & 79 & 63 \\
\hline & $\mathrm{R}$ & 185400 & 97 & 97 & 101 & 91 & 91 \\
\hline & GM & 38931 & 86 & 86 & 105 & 90 & 82 \\
\hline \multirow{3}{*}{$\begin{array}{l}\text { (11) Pig farming } \\
\text { (fattening) }\end{array}$} & $\mathrm{BP}$ & 16005 & 77 & 77 & 47 & 84 & 65 \\
\hline & $\mathrm{R}$ & 284983 & 99 & 99 & 97 & 95 & 95 \\
\hline & GM & 58969 & 94 & 94 & 86 & 96 & 90 \\
\hline
\end{tabular}

Legend: BP - budgetary payments, $\mathrm{R}$ - revenue, $\mathrm{GM}$ - gross margin 
single payments or a more environmentally demanding eco-scheme would lead to a reduction of around $15 \%$. Scenarios D and E importantly reduce support, which can, in extreme cases, even fall down to a third of current funds. The impact of revenue changes in agricultural policy measures is low (a $2 \%$ reduction at most). For this type of farms, the focus of agricultural policy should also be shifted from direct payments to establishing a more effective system of risk management measures.

On the type of farm engaged in intensive milk production (4), CAP income payments would currently amount to EUR 30000 and are strongly based on historical rights. This represents about $15 \%$ of revenues and a quarter of GM. A farm with GM of EUR 127000 seems an attractive option, and if the farm is not over-indebted, it enables good management. Notwithstanding the reliance of this farm's performance from the assumptions about its indebtedness, it allows for a discussion on the fundamental issues of intensive dairy cow breeding. Budgetary payments for this farm will be significantly reduced after 2022 - by at least 40 to $55 \%$ regardless of the scenario, mainly as a result of the projected loss of historical rights. Scenarios that assign higher values to arable land (scenario D) turn out somewhat better, and those that favour smaller farms (scenario E) turn out worse, but these differences are not very large. Regardless of these losses in budgetary payments (around EUR 15000), such changes alone may not pose a direct threat to the existence of such farms (in all scenarios, they would still reach around $90 \%$ of baseline GM). The share of budgetary payments is relatively low, so the success of such breeding is not solely due to budgetary support, although the reduction of payments and the consequent reduction of the GM by more than $10 \%$ will present a significant challenge. However, we believe that the key challenge of such farms is in the optimization of technology, prudent investment management, as well as economies of scale.

The second type of specialised milk farm (5) illustrates the potential effects for smaller, medium-intensity dairy farms. In the farm's revenue, which is estimated at around EUR 70000, the CAP payments in question contribute around EUR 9000. The gross margin is around EUR 44000, so the economic situation of such a farm is highly dependent on cost management and the purchase price of milk. The conclusions of the scenario analysis are similar to the previous case (larger specialized dairy farm). This means a reduction in direct payments by approximately half due to the loss of historical payments; there are no major differences between the scenarios (the 'socially oriented' scenario E, which favours smaller farms, would be the most favourable for this farm). The decrease in GM ranges up to $10 \%$ in all scenarios.

The scenario analysis also reveals similar effects on the economic performance for the farm that combines dairy production and beef (6). The estimated baseline revenue of the farm is about EUR 56000, of which about EUR 8000 is from CAP payments. GM is estimated at EUR 32000 per year. Budgetary support represents $14 \%$ of revenue and $24 \%$ of gross margin. All scenarios significantly reduce budgetary support by 30 to $45 \%$. Here, too, this is mainly the result of the loss of historical support. On this farm, changes in budgetary payments lead to approximately the same changes as on other cattle farms with milk production, which is again mainly the result of the loss of historical part of the payments. The farm has long-term problems with accumulating funds for investment, and the value of labour inputs relative to gross margin depends substantially on the level of purchase prices.

On farms with a more extensive production orientation, such as the farm focused on rearing suckler cows and fattening offspring (7), the share of budgetary payments in the structure of total revenues (around EUR 85000 ) is higher, in this case around one fifth, or more than half of the created margin. All of the envisaged scenarios reduce the amount of support due to a general reduction in payments and the loss of historical bonuses. These losses are largest in the 'social' scenario E. On the other hand, the production-oriented scenario (D), with higher differences between extensive and intensive land use, approaches the current payment levels the most. The results of the scenario analysis predict a deterioration in the economic situation of the farm up to a $15 \%$ reduction in created gross margin. Dependence on support is significant, so this type of farm should think strategically about future production or market orientations that would lead to a significant increase of revenue (e.g. entering quality schemes, as well as increasing farm size and/ or production volume).

Among the analysed types of farms, the largest expected changes in the model of implementing CAP direct payments are found on the farm that is specialised in fattening (mainly purchased) bulls (8). Estimated revenue is about EUR 112000, of which $14 \%$ is budgetary payments. Due to high variable costs of such production laying on purchase of calves, gross margin is low (EUR 25000) and is greatly determined by CAP payments (64\%). These are largely the result of historical support, which the reform is abolishing. This is also reflected in the dramatic reduction in budgetary support for this type of farm by up to $65 \%$ (scenario E). This type of farm and its variants are therefore quite endangered. The question of gradually abolishing historical rights is more than appropriate. Strategic consideration is necessary not only at the level of the individual farm, but also at the level of the entire production orientation. 
There are several alternatives in the proposal for the future CAP payment regime that allow high payments for production orientations aimed at extensive animal husbandry on grassland. A typical example of such an orientation is the analysed sheep farm (9), whose estimated revenues in the initial situation amount to EUR 59000 , 36000 of which $(61 \%)$ stem from budgetary payments. In the market area, it even operates at a loss, as direct support exceeds gross margin by $18 \%$. This is the type of farm where the biggest differences between scenarios occur. The simplified scheme (B) increases revenues by $50 \%$ and the environmentally oriented eco-scheme of scenario $C_{b}$ increases them by as much as $100 \%$. However, a different level of payments for different land uses, which allocates smaller amounts to extensive grassland, and the socially oriented scenario $\mathrm{E}$, which gives more to smaller farms, can dramatically reduce payments, by as much as $80 \%$. Due to the high level of dependence on subsidies, the gross margin and thus the viability of this farming model is highly dependent on the choice of policy model.

We also included two pig farms in the scenario analysis. In the first case (10) we are dealing with a cropgrowing farm that supplements its income with breeding of home-bred piglets at a small scale. The revenues of this type of farm are estimated at EUR 185000, of which EUR 19000 are area-based direct payments $(10 \%)$. The farm would reach EUR 39000 of GM, with direct payments amounting to almost half of that value. As in the case of larger arable farms, policy change is accompanied by the same effect of the predicted scenario change. Most support is decreasing, which is especially evident in the socially-oriented scenario that supports smaller farms (E), while including a farm in an eco-scheme with a weaker environmental ambition $\left(\mathrm{C}_{\mathrm{b}}\right)$ would lead to a $10 \%$ increase in revenues. Budgetary support is an important, but not a key factor in maintaining and developing such farms. The key lies in the level and stability of purchase prices, as well as in greater technological efficiency, but especially in economies of scale and improved breeding productivity parameters.

The second type of pig-rearing farm (11) is marked by high market sales and consequently has a high yearly revenue of EUR 285000. Budgetary payments contribute $6 \%$ to this, and represent a quarter in the structure of GM. Of course, this is a type of farm where the economic situation can change dramatically very quickly with changes in the prices of piglets and fatteners. All the scenarios in question bring this farm a reduction in support; from $16 \%$ in the scenario rewarding intensive land use (D), to a reduction of more than $50 \%$ (due to the size of the farm) in scenario E. Despite the not-insignificant revenue consequences of CAP income payments, we allow ourselves the conclusion that the long-term resilience of this type of farm depends primarily on price ratios in pig farming, as well as an uninterrupted supply of weaners.

\section{CONCLUSIONS}

We conducted the research on the income effects of the various agricultural policy options beyond 2022 by simulating changes in revenues and variable costs (gross margin) on selected 11 typical farms. These are types of farms that are above-average in size, volume of production, and most also in production intensity. They are located in different types of areas (plains, various less favoured areas). Following the example of the Impact Assessment that was carried out for the same purpose for the European Commission (European Commission, 2018b), we developed a set of scenarios that define simplification, environmental orientation, production and social aspects in line with the possibilities offered by the European Commission's proposal for future measures (European Commission, 2018a) and the 2018 CAP budget (Matthews, 2020).

\subsection{ANALYSIS OF INCOME EFFECTS BY TYPES OF (SPECIALISED) FARMS}

Future changes will lead to a reduction in budgetary support in most of the farm types and scenarios considered. Farms with predominant extensive animal husbandry on grassland are an exception if a sufficiently funded income based eco-scheme is introduced. The reductions are mainly the result of a reduction in the 2018 envisaged total amount of available funds, in certain types also of the abolition of historical payments. Cattle farms are a story into themselves, where a larger drop in CAP direct payments is expected due to the loss of historical support, making this decrease an important, perhaps even key change for cattle-breeding types of farms. Namely, the current (2015-2020) programming period was marked by an only gradual adjustment of direct payments and therefore an important part of the historical element was still present in 2017. Scenarios for changes in agricultural policy assume an immediate transition to equal area-based payments, depending on the type of measure, but they no longer include top-ups for individual farms.

The magnitude of the effects of agricultural policy on farms' gross margins is most visible in those sectors and types of Slovenian agriculture where budgetary transfers represent the largest revenue item. This definitely includes beef fattening as well as small ruminant 
production. The situation in these two cases is different, as the abolition of historical rights affects cattle fattening the most. In other types there are reductions, but changes in gross margins can still be managed with appropriate strategic changes on holdings. Changes in agricultural policy must therefore be viewed mainly in light of changes in GM, and not so much in terms of what share of funds an industry or farm type may lose (in absolute or relative terms). Fruit growing, viticulture, pig farming, and to a large extent also milk production, can overcome changes more easily than cattle fattening, for example.

An important message of the results of the scenario analysis is that, in the discourse on strategic planning of agricultural policy for the future, more attention needs to be paid than before to those farm resiliency strengthening measures that bring qualitative progress in terms of higher and more stable market revenues. Improvements in technology are related to this, as are improvements in farm management and marketing, and not only in primary agricultural production, but along entire value chains. Improvements are also needed in risk management. The proposal for the future CAP predicts the possibility of allocating part of the funds of the first pillar (up to $10 \%$ ) for the upgrade of the risk management system. Sectors that are particularly exposed to production risks (e.g. viticulture, fruit growing, crop-growing) would benefit the most from a more ambitious agricultural policy approach in setting up a risk management system. However, here we must take into account that the introduction of risk management support will bring an additional redistribution of money between sectors or farm types, which would not significantly impact the economic situation of most of the types of farms considered.

\subsection{SCENARIO ANALYSIS OF INCOME EFFECTS}

The scenario with a simplified payment scheme (B) provides virtually all of the funds of the first pillar in the form of a single payment. The results on the economics of production are neither particularly bad nor good. Because the sum is relatively large, it supports extensive producers the most, but it also brings some stability for intensive producers, regardless of orientation. In terms of agricultural policy, it could be understood as some sort of support for all producers, who then have to decide what they will produce. The model of agricultural policy support would certainly be simplified.

Both 'green' scenarios $\left(\mathrm{C}_{\mathrm{a}}\right.$ and $\left.\mathrm{C}_{\mathrm{b}}\right)$ are based on different types of eco-schemes, depending on how many resources and for which areas they would be allocated. The conditions tied to these measures were not explicitly modelled, as all conditioning is also associated with certain costs, which we could not predict at this stage of drafting the new policy. Therefore, these particular results need to be taken with a grain of salt. In some types of farms (crop-growing and pig farms, to a lesser extent also milk production) eco-schemes have proved to be a possible way of compensating for the loss of budgetary support. This is logical, because we can direct additional funds to certain types of holdings with them, but of course they must also yield certain environmental results. We must therefore be careful in interpreting the results of this analysis, which has, however, certainly indicated that the combination of the basic payment and the appropriate choice of eco-scheme can give sound economic results.

The production scenario (D) is based on different levels of payments for different types of land use (extensive uses would receive less, whereas arable land and permanent crops, for example, would receive more). Based on the model results, we are not convinced by this scenario. Extensive grassland was used in the breeding of small ruminants, and there the effect was seen (correction of "high" public support for this category of use). For others, it has brought slightly smaller losses in budgetary support, but these are not very pronounced. For some types of farms, the effect is offset because they have diversified land-use; otherwise the effect depends on the degree of differentiation of payment for more extensive grassland. However, the administrative complexity of introducing and implementing such a payment system should not be underestimated.

The social scenario (E) is based on different levels of payments for different sizes of holdings, as well as on production-coupled payments, thus supporting smaller holdings. In this scenario, too, the seekers of solutions to all issues within the proposed agricultural policy model find themselves in a trap. Small farms cannot be helped merely with per-hectare payments. No matter how much we try to increase these amounts, the total yield is too poor for this way of farming to be maintained in the long run. Smaller farms could only be helped by an income payment, which is a payment per person working on such farm. This would lead to a radical change, which the CAP does not envisage at the moment, and the funds for such plans would also run out very quickly.

\subsection{MODEL AND APPROACH}

Our scenario analysis also served as a test of the method and applied approach. It turns out to be useful, however applied approach needs to be strengthened in the future by choosing a selection of farms that is wider and more adapted to realistic conditions, which will 
show the full diversity of conditions and variety of potential effects. The farm model and its basis also need to be adapted. However, model calculations that are based on the detailed breakdown of the production function did turn out to be a good substitute for bookkeeping data. Due to the weakness of the FADN database in Slovenia, which stems from the facts that it does not record detailed sectoral costs, is practically not used and does not have sufficiently developed control assessments that would raise quality, the chosen approach is also the only feasible one. Such an approach can also be an alternative for other countries with poorer quality of bookkeeping data and ought to be tested, but establishing such a system does require a great deal of effort and investments.

Regardless of the narrow selection of typical farms and the limitations of the methodological tool, we estimate that the presented approach enables the implementation of agri-policy relevant analyses and evaluations. The scenario analysis of future changes in agricultural policy provides a broader insight into the extent of changes and the state of the economic situation of individual types and production orientations of farms and thus of agriculture as a whole. The assessment opens up new insights and provides an opportunity for in-depth discussion, which, considering the new, more strategic and goal-oriented manner of defining measures, could be important for its future development. The biggest advantage of this approach is that we assess the redistributive effects of different direct payment schemes in light of the total revenues and gross margins, where it is clear that not all sectors and types within them are equally economically dependent on support.

A specific limitation of the proposed approach is that the microeconomic analysis, by not including fixed costs, does not take into account the overall financial and operating situation of a farm, which can have a significant impact on its economic situation. If a farm is indebted, its position is significantly more fragile and budgetary support is an important part of its liquidity and solvency. The inability to cover at least the bulk of amortisation most often occurs with larger and more technologically demanding types of farms and can be a significant obstacle to a farm's operation. In the future, it will be necessary to take this into account and also provide for an analysis of total costs, taking into account the different levels of indebtedness of farms.

We did not include agri-environmental and climate measures and measures to support organic farming in the analysis. For some of the types of farms considered, this is an important source of income, sometimes even more than direct payments. We did not consider them because future environmental measures are not defined, but if we simply continued with the same ones as before, this could yield a wrong picture, while leaving their actual impact un-analysed.

\section{REFERENCES}

AIS (2019). Model calculations. Internal electronic source. Agricultural Institute of Slovenia, Ljubljana. (Unpublished raw data).

Alons, G. (2019). The advantage of paradigmatic contestation in shaping and selling public policies. Journal of Public Policy, X, 1-21. https://doi.org/10.1017/S0143814X19000060

Coleman, W.D. (1998). From protected development to market liberalism. Journal of European Public Policy, 5(4), 632-651. https://doi.org/10.1080/13501769880000061

Daugbjerg, C., Swinbank, A. (2016). Three decades of policy layering and politically sustain-able reform in the European Union's agricultural policy. Governance, 29(2), 265-280. https://doi.org/10.1111/gove.12171

Erjavec, K., Erjavec, E. (2020). The noble or sour wine : European Commission's competing discourses on the main CAP reforms. Sociologia ruralis: journal of the European society for rural sociology, 60(3), 661-679. https://doi.org/10.1111/ soru. 12300

European Commission. (2018a). Regulation of the European Parliament and of the Council establishing rules on support for strategic plans to be drawn up by Member States under the Common agricultural policy (CAP Strategic Plans) and financed by the European Agricultural Guarantee Fund (EAGF) and by the European Agricultural Fund for Rural Development (EAFRD) and repealing Regulation (EU) No 1305/2013 of the European Parliament and of the Council and Regulation (EU) No 1307/2013 of the European Parliament and of the Council. Brussels. Available at https:// eur-lex.europa.eu/legal-content/EN/TXT/HTML/?uri=CELEX:52018PC0392\&from $=\mathrm{EN}$

European Commission. (2018b). Commission staff working document - Impact Assessment. Accompanying the legislative proposals on support for strategic plans to be drawn up by Member States under the Common agricultural policy (CAP Strategic Plans), on the financing, management and monitoring of the common agricultural policy and establishing a common organisation of the markets in agricultural products. Brussels. Available at http://ec.europa. eu/transparency/regdoc/rep/10102/2018/EN/SWD-2018301-F1-EN-MAIN-PART-3.PDF

European Commission. (2020). Common agricultural policy indicators. Available at https://ec.europa.eu/info/food-farming-fisheries/farming/facts-and-figures/performance-agricultural-policy/cap-indicators_en

Hill, B. (2018). Farm Income. Wealth and Agricultural policy. 3rd ed. Routledge, London. https://doi. org/10.4324/9781315201696

Kavčič, S., Erjavec, E. (2003) Ocena dohodkovnega položaja slovenskega kmetijstva po pristopu k Evropski uniji. In: Kavčič, Stane (ur.), Erjavec, Emil (ur.), Kuhar, Aleš (ur.). Slovensko kmetijstvo in Evropska unija. 1. izd. Ljubljana: Društvo agrarnih ekonomistov Slovenije - DAES. 37-52. 
Langrell, S., Ciaian, P., Espinosa, M., Gomez Paloma, S., Heckelei, T., Louhichi, K., Sckokai, P., Thomas, A., Vard, T. (2013). Farm level modelling of CAP: a methodological overview. Joint Research Centre Scientific and Policy Reports. Luxenbourg: European Union.

Lee, N., Kirkpatrick, C. (2006). Evidence-based policy-making in Europe: an evaluation of European Commission integrated impact assessments. Impact Assessment and Project Appraisal, 24(1), 23-33. https://doi. org/10.3152/147154606781765327

Lovec, M., Šumrada, T., Erjavec, E. (2020). New CAP delivery model, old issues. Intereconomics, 55(2), 112-119. https:// doi.org/10.1007/s10272-020-0880-6

Matthews, A. (2020). When the CAP budget pendulum finally stopped swinging. CAP Reform blog. Available at http://capreform.eu/when-the-cap-budget-pendulum-finally-stopped-swinging/

Rednak, M., Erjavec, E., Volk, T., Kavčič, S. (2005). Distributivni učinki spremenjene politike neposrednih plačil na slovensko kmetijstvo. In: KAVČIČ, Stane (ur). Slovenija $v E U-i z z i v i$ za kmetijstvo, živilstvo in podeželje. 3. konferenca DAES, Moravske Toplice, 10.-11. november 2005. 1. izd. Ljubljana: Društvo agrarnih ekonomistov Slovenije DAES. 13-27.

Rednak, M., Erjavec, E., Volk, T., Zagorc, B., Moljk, B., Kavčič, S., Kožar, M., Turk, J., Rozman, Č., Vučko, I. (2009). Analysis of the effects of agricultural policy with the model of typical agricultural holding. Final report of the project V40361. Ljubljana: Agricultural Institute of Slovenia.

Reidsma, P., Janssen, S., Jansen, J., van Ittersum, M. K. (2018). On the development and use of farm models for policy impact assessment in the European Union - A review. Agricultural Systems, 159, 111-125. https://doi.org/10.1016/j. agsy.2017.10.012

Salamon P., Banse M., Barreiro-hurlé J., Chaloupka O., Don- nellan T., Erjavec E., Fellmann F., Hanrahan K., Hass M., Jongeneel R., Laquai V., vanLeeuwen M., Molnár A., Pechrová M., Salputra G., Baltussen W., Efken J., Hélaine S., Jungehülsing J., von Ledebur O., Rac I., Santini F. (2017). Unveiling diversity in agricultural markets projections: from EU to Member States. A medium-term outlook with the AGMEMOD model. JRC Technical Report, Publications Office of the European Union, Luxembourg.

Severini S., Tantari A. (2015). The distributional impact of agricultural policy tools on Italian farm household incomes. Journal of Policy Modeling, 37(1), 124-135. https://doi.org/10.1016/j.jpolmod.2015.01.004

Sinabell, F., Schmid, E., Hofreither, M. F. (2013). Exploring the distribution of direct payments of the common agricultural policy. Empirica, 40(2), 325-341. https://doi.org/10.1007/ s10663-012-9194-7

Šumrada, T., Lovec, M., Juvančič, L., Rac, I., Erjavec, E. (2020). Fit for the task? Integration of biodiversity policy into the post-2020 Common Agricultural Policy : illustration on the case of Slovenia. Journal for nature conservation, 54, 1-11. https://doi.org/10.1016/j.jnc.2020.125804

Van Tongeren, F., Van Meijl, H., Surry, Y. (2001). Global models applied to agricultural and trade policies: a review and assessment. Agricultural Economics, 26(2), 149-172. https:// doi.org/10.1111/j.1574-0862.2001.tb00060.x

Volk, T., Brečko, J., Erjavec, E., Jerič, D., Kavčič, S., Kožar, M., Moljk, B., Rednak, M., Zagorc, B., Žgajnar, J. (2017). Development of a comprehensive farm model and related databases to support decision-making in Slovenian agriculture (V4-1423). Final report V4-1423. Ljubljana: Agricultural Institute of Slovenia.

Žgajnar, J., Kavčič, S. (2016). Optimal allocation of production resources under uncertainty: application of the multicriteria approach. Zemědělská ekonomika, 62(12), 556-565. https://doi.org/10.17221/238/2015-AGRICECON 